\title{
Religion and Climate Change: Rain Rituals in Israel, China, and Haiti
}

\author{
Gerald Murray * and Haiyan Xing * \\ Department of Sociology, Shanghai Normal University, Shanghai 200234, China \\ * Correspondence: murray@ufl.edu (G.M.); xhydls@shnu.edu.cn (H.X.)
}

Received: 13 August 2020; Accepted: 19 October 2020; Published: 26 October 2020

\begin{abstract}
Human populations confront three distinct climate challenges: (1) seasonal climate fluctuations, (2) sporadic climate crises, and (3) long term climate change. Religious systems often attribute climate crises to the behavior of invisible spirits. They devise rituals to influence the spirits, and do so under the guidance of religious specialists. They devise two types of problem-solving rituals: anticipatory climate maintenance rituals, to request adequate rainfall in the forthcoming planting season, and climate crisis rituals for drought or inundations. The paper compares rainfall rituals in three different settings: Israel (Judaism), Northwest China (ethnic village religion), and Haiti (Vodou). Each author has done anthropological fieldwork in one or more of these settings. In terms of the guiding conceptual paradigm, the analysis applies three sequentially organized analytic operations common in anthropology: (1) detailed description of individual ethnographic systems; (2) comparison and contrast of specific elements in different systems; and (3) attempts at explanation of causal forces shaping similarities and differences. Judaism has paradoxically maintained obligatory daily prayers for rain in Israel during centuries when most Jews lived as urban minorities in the diaspora, before the founding of Israel in 1948. The Tu of Northwest China maintain separate ethnic temples for rainfall rituals not available in the Buddhist temples that all attend. The slave ancestors of Haiti, who incorporated West African rituals into Vodou, nonetheless excluded African rainfall rituals. We attribute this exclusion to slavery itself; slaves have little interest in performing rituals for the fertility of the fields of their masters. At the end of the paper, we identify the causal factors that propelled each systems into a climate-management trajectory different from that of the others. We conclude by identifying a common causal factor that exerts a power over religion in general and that has specifically influenced the climate responses of all three religious systems.
\end{abstract}

Keywords: Judaism; Chinese ethnic religion; Haitian Vodou; climate change; drought; rainfall rituals

\section{Introduction}

Human populations through the ages have been confronted by three distinct meteorological challenges: (a) seasonal climate fluctuations, (b) sporadic climate crises (such as droughts, inundations, hurricanes), and (c) long term climate change. Challenges (c) and (b) are interrelated; climate change increases the frequency and severity of sporadic climate crises.

Though the theme of climate change has surged in current international discourse, ethnographers have been recording statements from elders around the world, principally in agrarian villages, about the "good old days" when the skies behaved as they are supposed to. Some decades ago, one of the authors (Murray 1968), while doing research in the Spanish Caribbean, recorded verbatim laments from farmers about how the rains had diminished over the years sabotaging the viability of their livestock-raising slash-and-burn agropastoral economy. When asked why the rains had stopped, an elderly Dominican farmer answered in the Spanish dialect spoken in the mountains of the Cordillera Central: 
Well, some people say it's because the mountains have been stripped of trees. But that's not so. No, señor! Like the elders used to say, this is the fulfillment of a prophecy. It had to happen. The rains were going to become scarce. These hills were going to be covered with roads. We used to say, "No, that can't possibly happen ... You have to be stupid to believe that!" Is that so? Well just look. The hills are crisscrossed by roads everywhere! ... Our animals are disappearing. They say that there will be a time where children will ask their fathers, "Papá, what kind of a bone is that?" And the father will answer, "Mi hijo, that belonged to an animal that we used to call a cow ..." .

(Murray 1968, pp. 92-93)

The farmers interviewed knew well the effects of diminished rains on their livelihood. However, they had folk-explanatory theories about the remote unseen causes of this process. Additionally, as has been true of populations around the world, both normal climate fluctuations and aberrant weather crises are viewed as under the control of an invisible but powerful spirit world. It should also be noted: even popular awareness of anthropogenic factors does not preclude the attribution of climate change to supernatural beings. The Dominican farmer cited above knew well that it was a sawmill company, not the Dios of his Catholicism, that transformed the mountain ecology with lumber-extraction roads; farmers also know that the long term decline in rainfall is somehow related to the removal of tree cover. That does not, however, prevent the inclusion of invisible spirits as remote causal agents of the crisis. Humans cut trees and build roads, but the invisible spirit world has power to guide (or permit) the human behaviors that are the immediate efficient causes of climate crises.

It is here that religion has entered throughout human history. In these pages, "religion" is defined as a cultural subsystem with cognitive, behavioral, and organizational components: belief in invisible spirits, rituals to interact with the spirits, and specialist leaders who guide others as to the nature of the spirits and the rituals needed to influence them. Across the globe and throughout history, climate fluctuations and crises have been attributed to the action of invisible spirit beings. However, religions go beyond folk-theological speculation. Under the guidance of specialist/practitioners believed to have more knowledge of and/or power over the spirits, ritual interventions are designed to manage the weather. There are two generic types of rituals. The most frequent are the climate maintenance rituals that occur before the expected rainy season to petition the invisible powers to send the right amount of rain at the right time. There are also climate crisis rituals that spring into action when the skies (and/or the spirits) are misbehaving, either by withholding rain or by sending catastrophic deluges or hurricanes.

In these pages we will be exploring the involvement of three distinct religious systems in climate issues. Our approach will be ethnographic, focusing on systems in which each of the authors has carried out field research. We will compare three distinct, unrelated religious systems in terms of their ritual involvement with rainfall issues. In our comparison, we have been surprised at some of the patterns that have emerged. It is not only the skies that behave in unpredictable fashion. So also do religious systems.

All three of the systems to be studied here behave in counterintuitive ways with respect to weather. One of them has, for 2000 years, maintained obligatory daily rain-and-crop related rituals long after its practitioners ceased being farmers and had long ago left the only territory of relevance to the rituals. One would have predicted the disappearance of the rain rituals long ago. Another system places rainfall under the control of particular animal spirits that in the western world are considered to be demon-driven enemies of the human species. Additionally, the third system, whose adherents desperately need increasingly scarce rain for their fields and crops, have a ritually rich folk-religious system that nervously avoids rituals that would address climate issues.

The first religious system to be dealt with is the majority religion in Israel: Rabbinic Judaism, quite different in many core details from its historical predecessors Patriarchal Judaism and Temple Judaism. Murray spent several months on the Gaza strip in a religious agrarian Israeli moshav shortly before it was demolished by the Israeli government. He has also participated in hundreds of synagogue 
rituals in the U.S. and other countries and has taught courses in the Anthropology of Judaism. Another is the religion of the Tu ethnic group studied by Xing in Northwest China. They are an agropastoral group that is heavily involved in the Tibetan Buddhism that is the dominant religious tradition in the region of the Tibetan Plateau in which they live. However, they have maintained as well their own separate ethnic temples; the major function of Tu temple ritual at the moment is precisely that of managing critical but increasingly unpredictable rainfall, an option that is not available in the Buddhist rituals in which they also participate. The third is the religion that arose among African slaves in the French colony of Saint-Domingue and that has persisted as Haitian Vodou. It is a theologically and ritually complex folk-religion that emerged during slavery and that survived after the slave revolt and national independence in 1804. Murray spent nearly two years in a village where Vodou was practiced by some $60 \%$ of the village population. He has made multiple return visits to the village, the most recent one being in 2017.

Both authors are anthropologists. Our methods were accordingly based on observations and interviews carried out in the local languages (Hebrew in Israel, Qinghaihua and Mandarin in Northwestern China, and Creole in Haiti.) In Haiti, Murray in addition carried out $100 \%$ surveys of the entire village including questions that dealt with involvement in Vodou. Our goal in these pages goes beyond ethnographic description. We assume that the structure of religious belief and ritual is not a product of cultural whimsy; the evolution of religious systems is driven by causal factors, at least some of which can be tentatively identified. We will venture into explanatory efforts at the end of the article. After first presenting some basic ethnographic information on each of the systems, in the end we will identify some factors that may help explain the counterintuitive trajectories into which the different religious systems have veered in their shifting cultural-evolutionary involvement with rainfall and crops. We will see that the response of religious systems to climate crises is governed not only by climate fluctuations and ecological factors. The nature of ritual responses to rainfall is also governed by sociopolitical factors that operate independently of objective environmental factors. We will see that the exercise of State power has affected all three systems.

\section{Israel: Judaism and Climate Concerns}

Israel is located on the southeastern coastline of the Mediterranean Sea. Currently it has an estimated 2020 population of 9.2 million living on $21,000 \mathrm{~km}^{2}$, yielding a per $\mathrm{km}$ population density of 417 per $\mathrm{km}^{2}$, the highest of the three countries considered here. It also has the highest annual per capita GDP of over $\$ 40,000^{1}$. In terms of religion, $74 \%$ of Israelis are Jews; they practice Judaism with varying levels of observance (or non-observance). 18\% of Israelis are Arab Muslims, and 2\% are Christians, most of the latter being Arabs.

We will examine here the surprisingly high level of explicit concern for climate and field crops in the daily, weekly, and annual liturgy of Rabbinic Judaism, the religion of the Jewish majority in Israel. The word "surprising" is not an over-dramatization. As we will see, the obligatory climate-related passages in the daily Jewish liturgy deal only with rainfall and crop fertility explicitly in Israel/Palestine. The Babylonian Talmud, which was compiled during centuries when Jews were still farmers, did modify the timing of the prayer for dew and rain to accommodate the timing of the rainy season in nearby Iraq. Jews around the world in subsequent ages adopted this modified timing but made no accommodations to the rainy season in their specific countries. The text of the prayers accommodate the rainy season only in Israel and Babylon.

However, for some two millennia, before massive Jewish immigration to British-controlled Palestine and (as of 1948) to the State of Israel, almost the entire Jewish world lived as urban minorities in diaspora countries around the world engaged in non-agrarian pursuits. Their prayers for rain in

1 The Central Intelligence Agency (2019) factbook, which compiled the statistics, also included the Golan Heights and East Jerusalem. 
Palestine, which they recited word-for-word from the synagogues of urban Europe, North and South America, North Africa, and elsewhere, would have benefitted the Muslim farmers who replaced the Jews several centuries ago. ${ }^{2}$ Did diaspora Jewry entertain sustained conscious humanitarian concern during centuries for the Muslim farmers of Palestine? It is unlikely. The counterintuitive survival of these prayers demands, first, documentation, and then explanation.

\subsection{Rabbinic Judaism and Its Predecessors}

To place Judaic weather prayers in historical context, it is useful to distinguish three historical phases of Judaism. Patriarchal Judaism was the religious system that emerged under three founding ancestral figures described in the book of Bereshit (Genesis) of the Hebrew Bible: Abraham, his son Isaac, and his grandson Jacob. Biblical texts describe them all as livestock raisers. None were farmers. The principal ritual offered to the Hebrew God was decentralized animal sacrifice carried out by the founding patriarchs on stone altars constructed on hilltops. In this phase of Judaism, there is no textual evidence for ritual concern with the rains. The promised reward for fidelity to the covenant was not abundant rainfall and crops, but abundant offspring and a land of their own. The patriarchs experienced drought and famine. Their response to drought was emigration to irrigated Egypt, not rituals to bring the rains to Canaan or to the other territories where they lived.

The next phase, Temple Judaism, arose after the establishment of an Israelite monarchy and the subsequent building of a temple in Jerusalem. At that time, the Hebrews (by then called bnei Israel—children of Israel or Israelites) were no longer pastoral nomads, but hillside farmers with livestock as a secondary pursuit. The core ritual of Temple Judaism continued to be animal sacrifice. It was, however, restricted. It could be done only inside the Jerusalem Temple and could be performed only by a hereditary priestly caste. Since the Israelites were by then hillside farmers practicing rainfall agriculture, concern with drought figured prominently in the scriptures dealing with this period. However, there is no evidence that rainfall-related texts were incorporated into daily and weekly liturgies. The core of Temple Judaism focused on thrice-annual pilgrimages to Jerusalem for animal sacrifices in the Temple, not on the daily synagogue liturgy, including prayers for rain, that is performed today.

All of this changed when the Temple was destroyed for the last time by the Romans in $70 \mathrm{CE}$, and Rabbinic Judaism emerged. The Jewish priesthood could no longer function in their major role (animal sacrifice). The new leaders who emerged were the rabbis, who had been scholars and teachers in the centuries when the Temple stood. Formerly of less authority than the Jerusalem high priesthood, the rabbis eventually found themselves in the position of leadership vacated by the now-unemployed sacrificial priesthood.

The rabbis preserved Judaism by switching the focus from animal sacrifice. Rabbinic Judaism focused (and still focuses) on daily and weekly prayers in the synagogue, study of sacred texts, and meticulous observance of behavioral commandments and prohibitions. It was under the rabbis that rainfall concerns were incorporated into the heart of the evolving Jewish liturgy. For centuries after the destruction of the Temple, Jewish farmers continued to live in Palestine under foreign Roman and later Byzantine rule. Because they were farmers, rainfall concerns were built into the newly constituted daily and weekly synagogue liturgies.

The rebuilding of the Temple and restauration of animal sacrifice in a messianic future is a theme that was incorporated into the evolving Jewish liturgy. However, Judaism switched its ritual focus. The focus now was on observance of detailed rules concerning daily prayer, strict sabbath observance, food restrictions, menstrual laws, studious analysis and commentary on the scriptures,

2 There was always a small Jewish presence in Byzantine and Ottoman Palestine. However, this Jewish "Yishuv" was not agricultural. It consisted of urban religious Jews dedicated to Torah study, principally in Jerusalem but also in Safed and other cities. They were supported during centuries, not by farming, but by the halukka system, which solicited funds from the Jewish Diaspora for Jews studying Torah in the Holy Land. 
and the careful observance of hundreds of additional commandments. ${ }^{3}$ The rabbinic role and the meticulous observance of behavioral commandments had existed in embryonic form as local religious addenda to the core sacrificial rituals of the high priesthood ${ }^{4}$. However, rabbinic authority went from the periphery to the core of evolving Judaism.

After destruction of the Jerusalem Temple, rabbinic leadership emerged when the majority of Jews in Israel were still farmers concerned with fickle weather. Rainfall-related texts had been drafted when the Temple was still standing. It was under rabbinic leadership that they were incorporated into a newly created Jewish prayer book (siddur) as one of the obligatory daily elements of the Jewish liturgy. One clarification deserves repetition. The texts regarding rain and crops apply only to the Holy Land, to the "good land which the Lord is giving you".

\subsection{Rainfall Ritual in Judaism}

Let us now examine some of the rituals that to this very day religious Jews all over the world pray to ensure rains in Israel. Rabbinic Judaism mandates lengthy prayer three times a day, in the morning and afternoon, and in the evening after sunset. It emphasizes the obligatory nature of daily prayer, including those that allude to divine intervention in the rain and crops of Israel. Though of little direct relevance to Jews in the diaspora, they have been prayed by Jews, almost all of them in the diaspora, for two millennia.

There are at least four distinct elements of climate-related ritual in the Jewish prayer book, two of them part of the obligatory daily prayers: the Shma Israel, the Amidah, the Prayer for Rain, and the Prayer for Dew. The first is recited twice daily, the second thrice daily. The third and the fourth are each recited once per year when Israel's rainy season is about to begin and end.

\section{Rain Passage 1: The Shma Israel: Twice Daily Weather-Related Ritual in Judaism}

The core of the Shma Israel consists of a brief invocation (Hear, O Israel, the Lord is our God, the Lord alone ${ }^{5}$ ), followed by three scriptural passages. The second one (from the 11th chapter of Deuteronomy) focuses on rain.

And it will be, if you will hear and obey my commandments that I am giving to you today, to love the Lord your God and to worship Him with all your heart and with all your soul, I shall give rain for your land at the proper time, the early rain and the late rain, and thou shalt harvest thy grain, thy wine, and thine oil. And I will give grass in thy fields for thy cattle, and thou shalt eat and be sated. Take care lest your heart be lured away, and you turn astray and worship other gods and bow down to them. For then the Lord's wrath will flare up against you, and He will close the heavens so that there will be no rain and the earth will not yield its produce, and you shall swiftly perish from the good land which the Lord is giving to you. ${ }^{6}$

3 The traditional number of commandments by which Jews are bound is listed as $613 . \quad$ Of these, 248 deal with mandatory behaviors and 365 deal with forbidden behaviors. Except for seven "Noachide" laws binding on all humans, the 613 commandments are largely viewed as binding only (or principally) on Jews. Non-Jews, for example, are not viewed as sinners if they eat pork or work and travel on Saturday.

4 This is seen in the New Testament in differences between the strict ritual demands of the Pharisees and the more relaxed approach common in the popular Judaism of northern Galilee. This set the backdrop of the famous conflict between Jesus and the Pharisees (Pharisee in Hebrew means "separated-perushim"—not "hypocrite").

5 A traditional translation says "the Lord is One". The original command was an explicit prohibition against worshipping the deities of the nations that surrounded Israel. The ordinary English translation, however, construes the passage as a metaphysical affirmation of God's unity rather than a prohibition against idolatry. This affirmation of God's unity came to be emphasized by the rabbis in Christian Europe, with its trinitarian theology. This is a reinterpretation of the meaning of the original text: worship only the Hebrew God.

6 The translation is by Murray and departs slightly from conventional translations. At a certain point, our translation uses the archaic "thou" and "thy" forms to indicate that the Hebrew suddenly (and enigmatically) switches from the you-plural to the you-singular, which is not distinguished in modern English. The verb عبد ('avad) is translated as "to worship" rather 
This passage has been read in public services twice a day by religious Jews minimally for 1200 years and possibly for two millennia. Several things should be noted.

As the text indicates, the promises and threats apply only to the land of Israel—"to the land which the Lord is giving to you". If you disobey, you will "perish from the good land". The passage specifically mentions the crops-grain (wheat and barley), grapes, and olives-that were among the most important in the agriculture of the pre-monarchic Israelite farming tribes that inhabited the climatically challenged hill country east of the region's coastal plain.

What was the divine logic behind a puzzling gift of a climatically challenged Promised Land where the flow of milk and honey was so easily jeopardized? The same Deuteronomic text (11:10-12) explains why the Israelites were to practice rainfall agriculture rather than more prosperous irrigation agriculture.

For the land that you are entering to take possession of it is not like the land of Egypt, from which you have come, where you sowed your seed and irrigated it, like a garden of vegetables. But the land that you are going over to possess is a land of hills and valleys, which drinks water by the rain from heaven, a land that the Lord your God cares for. The eyes of the Lord your God are always upon it, from the beginning of the year to the end of the year.

In other words, God himself would see to the watering of Israelite fields via rainfall. Unlike Egyptians with their irrigation systems, Israel instead would have to look up to heaven and trust God to supply water. This meteorological reminder has been repeated twice a day by religious diaspora Jews for close to two millennia.

\section{Rain Passage 2: The Thrice-Daily Amidah: The "Standing Prayer"}

Along with the Shma Israel, the Amidah is the second core element in the Jewish daily prayerbook. It consists of 19 blessings (one of them inserted later as blessing \#12). The Amidah is recited silently, by obligation, three times a day in a standing position facing the Temple Mount in Jerusalem. When praying in a morning or afternoon minyan (a required quorum of ten), the prayer leader recites the Amidah out loud after all have said it silently.

References to divine intervention in the climate of Israel occur in the second and ninth blessings. The wording, however, has to be changed according to the season. During Israel's rainy season, blessing \#2 praises God, because he "mashiv haruach umorid hageshem" (brings the wind and causes rain to fall). During the dry season, either those words are omitted or (in certain siddurim) God is praised because he "morid hatal" (brings down dew). The worshipper must be sure to use the proper climate passage in the proper season. If a person makes a mistake and praises God for marshalling wind and rain during the dry season, the entire Amidah has to be repeated again from the beginning. Wind and rain could be harmful outside of their season. If the one praying mistakenly asks for dew instead of rain during the rainy season, there is less danger of grave harm, and the prayer need not be repeated.

Whereas blessing \#2 of the Amidah simply praises God's power over wind and rain, blessing \#9 contains an explicit petition concerning crops and moisture. During Israel's rainy season, the wording is "Bless this year for us, O Lord our God, and all its crops ... and give dew and rain as a blessing on the surface of the soil ... " As with blessing \#2, during the dry season the word "rain" is omitted. In some siddurim even "dew" is omitted.

The frequency of these climate-related prayers is astounding. Religious Jews all over the world recite blessing \#2 21 times per week. Blessing \#9 is recited 18 times during ordinary weeks, being omitted

than the more conventional "to serve". Anglophones generally go to religious events in synagogue, church, or mosque to "worship" rather than to "serve".

7 The ArtScroll Siddur (Sherman and Zlotowitz 1985, pp. 1078-79) lists eighteen complex rules governing procedures if an individual praying privately mixes up Israel's dry and rainy season in prayer. Recitation of the proper climate prayer is so crucial that many synagogues post a sign reminding those praying which passage to pray during the current season. See also (Donin 1980, pp. 78-80). 
on Sabbath (and Festivals). Taking into account the Shma Israel and the Amidah, the frequency of obligatory, explicit climate prayers in Judaism is substantially greater than has been documented in any other known religious system.

\section{Rain Passage Complex \#3: The Seasonal Prayers for Rain and Dew}

There are, however, other prayers as well. Rainy seasons begin only once a year in Israel, usually in October/November. Shortly before the winter rainy season (hopefully) begins, a special additional prayer for rain is inserted during a joyful late-Autumn festival called Shemini Atzeret. This particular rain prayer, which was drafted later during the Common Era, has an anthropologically interesting twist to it: It alludes to an angel (Af Bri) who is "Master of the Rain". In the evolution of Rabbinic Judaism, the number of angels was multiplied beyond the four who are mentioned by name toward the end of the Hebrew Bible. Angels were conceived as having been given dominion by God over different natural phenomena. The angel Af Bri is the "Sar Matar" (master of rain). No prayer is directed to the angel himself. The prayer is to God, requesting that he instruct the angel Af Bri to distribute rainfall and to "soften the wasteland's face when it is dry as rock". 8

\subsection{Crisis Measures: When the Hoped-for Rain Does not Materialize}

The major biblically recorded climatological crises affecting Jews are almost all associated with drought, not with flooding. With one possible exception, there are no formulaic prayers in the Jewish prayer book specifically drafted to counteract an ongoing drought, which has been a major problem both in ancient and contemporary Israel. In rabbinic Judaism, the ordinary daily prayers for rain continue to be prayed during times of drought. Under the rabbis during the Second Temple period and after, one standard response to drought was collective penitential fasting combined with the recitation of prayers, many taken from the book of tehilim (Psalms).

The Talmud (Talmud, Tanit 19a n.d.) also describes a particular Jewish wonder worker who brought rain in times of a persistent drought in the Holy Land during the first century BCE. Honi ha-Meagel (Honi the Circle-Drawer) drew a circle in the ground, stood in the circle, raised his eyes (but probably not his fist) and warned God that he was not leaving the circle until God sent rain. A tiny sprinkle came. "Not enough!" shouted Honi. A deluge came. "Too much!" The entire population of Jerusalem had to flee up to the Temple Mount because of the flood waters. Finally, the right amount came. Some rabbis wanted to excommunicate Honi for his dangerous impertinence. However, common sense prevailed, and they backed off. (What if the rains suddenly stopped?). Some commentaries give a more benign interpretation of why Honi was not excommunicated. The rabbis admired him for treating God as a Father who can be badgered by his child. Whatever the case, in accordance with Jewish theology, the Talmud indicates that it was not Honi, but God himself, who produced the rain.

To summarize: for two millennia, urban religious Jews all around the world have been in effect petitioning for rain in Palestine three times a day. It should be noted: This does not mean that the focus of Judaism is the weather. It is simply being pointed out that, whatever is considered to be Judaism's main focus, it is an empirical fact that climate issues are raised several times a day. If there has been a religion more concerned with the weather than Judaism, it has not yet been documented. The paradox is that virtually none of those diaspora Jews who for centuries prayed for rain in Palestine would have benefitted directly if the prayers were literally answered and the rain fell on Muslim farms. We will show in the analytic conclusion that in fact, despite the surface content of the liturgical texts, diaspora Jews were not in fact praying for the wellbeing of Palestinian Muslim farmers. However, first let us examine the rainfall concerns of two other religious systems.

8 Sherman and Zlotowitz (1985, p. 753). The Hebrew verb (yatriach), which we have rendered as "instruct", usually means "harass" or "bother". God is apparently being urged to make sure that Af Bri distributes the upper waters. The passage is written in a later (and often cryptic) form of Hebrew liturgical poetry called "piyyutim". The allusion to divinely provided rainfall, however, is clear. 


\section{Northwest China, Ethnic Religion, and Climate Concerns}

\subsection{Background to the Tu}

The Tu People (土族) are members of one of China's 56 officially recognized minority ethnic groups. At present (2020), there are over 200,000 of them living in different regions of China's Northwest, principally within Qinghai Province. The importance of rainfall in the religious beliefs and practices of the Tu is closely linked to their economy. Located on the northeastern edge of the Tibetan plateau, at an average altitude of $3000 \mathrm{~m}$, most Tu households still make their living from a combination of farming — principally wheat, barley, potatoes, and rapeseed (for canola oil)—and the raising of sheep, along with some horses, cattle, and pigs.

They are therefore highly dependent on rainfall. In Qinqhai Province, the rainy season is heaviest in the summer months of July and August and dwindles substantially in the winter. The rainfall rituals adapt themselves to this annual schedule. Most Tu regularly attend one or more of the multiple Tibetan Buddhist temples in the area; an outside observer might assume that they were Buddhists. However, they have also retained their own village temples. We will be examining the high level of concern with climate and crop issues in these ethnic temples.

Though not a daily concern as in Judaism, climate concerns are one of the factors that have motivated the Tu to maintain their own ethnic rituals. Whereas the literature on Judaism might fill a library and that of Vodou several bookshelves, the literature on Tu religion is much sparser. ${ }^{9}$ Subsequent to Xing's (2015) detailed study, various aspects of their religious system were subsequently analyzed by Xing and Murray $(2018,2019)$. Here we will focus on their beliefs and rituals insofar as they relate to climate and rainfall.

\subsection{Rainfall and Religion in China: Historical Overview}

Unlike the Abrahamic monotheistic traditions in the West, the religious systems of ancient China have never posited the existence of a personalized Supreme Being who created the world and its multiple lifeforms, who demands daily attention from worshippers, and who uses rainfall as a vehicle of reward or punishment for human behavior. In ancient China, rainfall was generally viewed as under the control of a theriomorphic ${ }^{10}$ spirit known as the Dragon King (longwang). This spirit eventually became pluralized as the Dragon Kings, less through draconian reproduction than through regional theogony. Major Chinese bodies of water in each of the four points of the compass were viewed as having their own Dragon Kings. Dragons in Western mythology have a bad name; they are viewed as fire-breathing winged destroyers. The Dragon King in Chinese tradition is the source of life-giving annual rains. ${ }^{11} \mathrm{He}$ has four feet but no wings, though he can float in the air as well as in water. Unlike his Western cousin, however, he never breathes destructive fire, never kidnaps helpless maidens, or is never killed by heroic warrior rescuers. Instead, he provides life-giving rain for the crops.

One suggestion is that the choice of the serpentine dragon as a symbol of rain may have derived from its shape that mimics that of the rainbow (Cartwright 2017). Cartwright's passage in the Ancient History Encyclopedia sums up the meteorological role of the dragon in ancient China.

In rural communities, there was a dragon dance to induce the creature's generosity in dispensing rain and a procession where a large figure of a dragon made from paper or cloth spread over a wooden frame was carried. Alternatively, small dragons made of pottery or banners were carried with a depiction of a dragon and written prayers asking for

9 A list of publications (many of them in Mandarin) dealing with the Monguor/Tu can be found online at https://en.wikipedia .org/wiki/Monguor_people.

10 Having the likeness of an animal. The term zoomorphic spirit (having a life-like form) is also used, which could include both non-human animal spirits and plant-like spirits.

11 Cartwright (2017) also points out the difference between the Chinese and the Western dragon figure. 
rain. Attendants would follow the procession carrying buckets of water and, using willow branches, they would splash onlookers and cry "Here comes the rain!". When it seemed that a drought was imminent, another appeal for rain was to draw pictures of dragons, which were hung outside the home. (Cartwright 2017)

We shall see below that dragon kings among the Tu have retained this essential connection with weather. Another major spirit in the Daoist pantheon, however, that also made her way into the Tu pantheon is Niang Niang. Her name is perhaps best translated as Queen Mother, in view of the regal stature and nurturing role attributed to her. Her traditional role, still found among China's Han majority, is associated with fertility and childbearing. She has maintained that among the Tu. However, the Queen Mother has also been reconceptualized among the Tu as having the same power over the weather as the Dragon King.

\subsection{Rain Rituals among the Tu}

We can now briefly discuss the climate-related rituals, discussed in greater detail in Xing (2015). There are standard seasonal weather-maintenance rituals near the onset of the rainy season. The purpose of these is to petition for normal rainfall and fertile crops. There are also, however, weather-crisis rituals, enacted when the spirits show themselves to be negligent (or, even worse, simply unable) to keep their side of the ritual bargain.

The anticipatory climate maintenance rituals take place at the onset of the spring planting season in the month of March. They take the form of an annual three-day festival known as the biangbianghui, enacted outside of the village temple that lodges the local dragon king or the local queen mother. The good will of the spirits is recruited via gifts that villagers give, either willingly or with some gentle arm twisting by the elected ritual committee. Entertainment with light-hearted music and ritual dancing is also a vehicle for pleasing the spirits.

The major officiant at these Tu festivals is the male bo, the major Tu shaman. The spirits do not remain invisible during this event. They become physically present by possessing the $b o$ as he engages in a skilled dancing ritual. The overriding function of this colorful spring festival, with its singing, dancing, possession events, and general recreational ambience, is to comply with the duty of entertaining the dragon kings and queen mothers in hopes that they will fulfill their part of the meteorological bargain for the crops about to be planted.

There are other rainfall rituals as well later in the agricultural cycle. The zhuanshanjing procession ritual is held in the fifth and sixth months of the lunar calendar, months that are crucial for the growing wheat crops. To ward off the dangers of sudden drought or destructive torrents or hailstorms, processions are made into distant mountain areas (usually by energetic youth) along the entire perimeter of the territory served by a village and its tutelary spirits. It may take five or six hours to make the entire round. During the procession, gongs and drums are beaten and Buddhist scriptures are carried aloft and chanted, not by the shaman, but by a Tu who is fluent in these texts. (Tu religion is based on oral tradition, not written text. However, the occasional presence of Buddhist texts adds social prestige to village rituals.) The spirits whose attention is being sought in this rainfall ritual include not only the dragon kings and queen mothers, whose litters are at the front of the procession, but also other mountain deities not necessarily lodged in village temples. The intended function of these processions is to fend off wind, hail, and frost that could harm the growing crops and to secure the continuation of favorable weather during the current growing season.

However, the maintenance of favorable weather is dependent, not only on ritual behavior, but also on human social behavior during the growing season. Conflicts within the village, and within households, are forbidden when the crops are growing. Husband/wife spats are seen as particularly dangerous during the growing season; spirits offended by domestic conflicts could retaliate with destructive hail. Harmony between spouses is thus converted into a vehicle for community benefits. 
The skies, however, do not always behave as they are supposed to. The rains may not come, or the rains may turn into harmful heavy downpours or take the form of destructive hail. There are separate crisis rituals to deal with such problematic climatic events.

The Tu have followed ancient Chinese traditions of punishing negligent spirits for inadequate or excessive rainfall-a response that would be unthinkable in Judaism (or Christianity or Islam). Among the $\mathrm{Tu}$, however, there are procedures for coercing and punishing local dragon kings and queen mothers who are not fulfilling their climate-related obligations. One measure is to physically remove them from their place in the main hall of the temple. They may then be demoted and sent to a secondary side hall where Buddhist statues are housed. It is hoped that the Buddhist spirits may reprimand the negligent local dragon king or queen mother and spur the recalcitrant spirits into action. The person responsible for administering this punishment is not the bo shaman, but the head of the village ritual committee.

In short, much of the ritual life of the Tu centers on rainfall-related beliefs and rituals. Most of the Tu also attend Buddhist temples in the area. Why then do they have their own separate temples? On the one hand, these temples maintain a sense of ethnic identity. However, they may also be compensating for a functional gap in Buddhist rituals. Unlike many local Buddhists, virtually all Tu are farmers and livestock raisers, heavily dependent on the rains. The annual cycle of Buddhist rituals, however, does not focus on agriculture, climate maintenance, or climate crises. In that light, the maintenance of local Tu temples for their dragon kings and queen mothers affords them a level of ritual control over the weather that is not available to them in the rituals of local Buddhism.

The frequency of Tu rainfall rituals is much less than the obligatory daily rituals that we have seen in Judaism. However, it is substantially greater than what is found in the third religious system that we will now examine, that of Haitian Vodou.

\section{Haitian Vodou}

\subsection{Haiti's Climate Dilemma}

Haiti's Creole speaking population shares the Caribbean Island of Hispaniola with the Spanish-speaking Dominican Republic to the east. The population of Haiti has been heavily involved with farming, not only as slaves in the French colony of Saint Domingue, but also as free smallholders after Haiti's successful expulsion of the French and its independence in 1804. Virtually the entire ex-slave population turned to farming their own small plots of land. Even by the 1970s, when one of the author's studies (Murray 1977) into the village of Kinanbwa ${ }^{12}$ first began, some $85 \%$ of Haitians were still living by farming, almost all of it dependent on rainfall rather than irrigation. Current demographic statistics, which document a massive rural exodus, indicate that the Haitian farming system has been devastated by numerous factors, not the least of which is a drastic increase in chronic drought conditions since the mid 20th century. The dramatic impact of climate change on rural Haitian life has been recently documented by Staub et al. (2020). Only 38.1\% of Haitians are still involved in agriculture. It is more than Israel's 1.1\% and even China's 27.7\% (CIA World Factbook), but much fewer than throughout much of Haitian history. The majority have abandoned the farming sector for life in urban centers or unskilled overseas labor. Climate change is one of the factors that has played a role in that exodus.

At the beginning of the article, we cited a Dominican farmer who commented on the dwindling rains. A Haitian farmer across the border also explained to Murray, in succinct Creole, why so many people were leaving farming: "Paske lapli ra pou tonbe..:Lè ou mete espwa sou lapli, l'pa tonbe" ("Because the rain now hardly ever falls. When you're counting on the rain, it doesn't fall.") He also said "Sa'k fe nou konn kite tè-a, se sezon ki ra. Nan pwen lapli, nou oblijie kite tè a". ("The reason

12 Kinanbwa is the pseudonym of a village in Haiti's Cul de Sac Plain. 
we leave the land is because the rainfall is scarce. There's no rain, so we have to leave the land.") At that time, in the 1970s, he meant "we leave the land unplanted". In recent decades, his children and grandchildren have been literally leaving the land to go elsewhere. His exact Creole words were "the season is rare", referring to the unreliable rainy season. Others, referring to drought, say "tan-an bouché", literally, "the time is blocked", meaning the rainy weather is blocked. The generic chronological terms "season" and "time" in village speech often allude to rainfall, a linguistic indicator of the importance of rain in rural Haitian discourse. The height of the village's rainy season comes from March to May. If it doesn't come, there is a problem.

However, the opposite problem also batters Kinanbwa. Haiti's location in the middle of the Caribbean hurricane belt has made it vulnerable to the opposite climate problem. Residents of the lowland village of Kinanbwa often must flee to higher ground when their village gets flooded out by hurricane winds or even unusually strong rainfalls. This, however, is a lesser threat than drought. Though hurricanes occur annually in the Caribbean, their distinct trajectories mean that a given country or region within a country will only occasionally be affected. Haitian farmers can adapt to, and with advance notice now prepare for, these occasional short term deluges. (cf. Staub et al. 2020).

Not so with drought. The increasing frequency of drought conditions during the "rainy season" has contributed to the destruction of the viability of farming in much of Haiti. Younger generations have left farming en masse to seek alternative occupations, often outside of Haiti. Over the decades since his first research, Murray has written letters for various young adults in Kinanbwa to help them acquire visas to the preferred destination, the U.S. With the tightening of U.S. immigration policy, however, dozens of young men in Kinanbwa, whose parents and grandparents were farmers and market women, are now going as far as Chile in their attempts to find wage labor. Climate change is by no means the sole driving force behind Haiti's desperate surge in emigration. However, if the rains were still as abundant as in the quickly fading distant past, farming would still be a viable fallback option, even in the face of the multiple economic and political crises that have battered Haiti in recent decades. It is, however, no longer a fallback option. On the contrary, with a 50\% chance in any planting season of losing one's crops to drought, the best option for young adults is to leave Kinanbwa to seek wage labor elsewhere, preferably outside of Haiti.

This would logically enhance the probability of rainfall rituals. If the evolution of rainfall rituals in a society is causally linked to the level of rainfall insecurity, we would have expected Haitian farmers to incorporate into their religious systems an even greater emphasis on rainfall rituals than what we have shown for Israel or China. For reasons that we will explore, the opposite has been the case. Religious systems in Haiti have on the whole not even addressed issues of climate. Adherents of all three major Haitian religions-Catholicism ${ }^{13}$, Protestantism, and Vodou—were found in Kinanbwa and in the communities studied by anthropologists Herskovits (1937), Metraux (1959), Conway (1978), Smucker (1984), and Richman (2005). Unlike Judaism and ethnic religion in Northwest China, however, none of the Vodou practiced in researched villages or towns in Haiti builds climate concerns into their core ritual system.

In the case of Catholicism and Protestantism, the absence of liturgical concern with rain and crops is no surprise. Unlike Judaism, whose liturgical texts took root in an epoch in which most Jews were ancient Near East farmers, the proto liturgy of Christianity took shape in the cities of the Greco-Roman world. The rural world largely continued practicing local "pagan" religions. The word "pagan" is, in fact, a pejorative Latin word for villager. Concern for rainfall and crops was felt largely by those then considered to be lower-status illiterate rustics, who at that time were practicing local religions.

13 Vodou adherents are also involved in Catholic rites. The Catholic group here refers to the subgroup of Catholics (katolik fran) that distance themselves from Vodou. Based on $100 \%$ survey of the research village, public adherents of Vodou constituted $62 \%$ of the village population, $23 \%$ were katolik fran, and $15 \%$ were evangelical Protestants. (Murray 1977). In the intervening decades the evangelical sector has become the majority. 
Their concerns with climate were understandably not incorporated into the evolving Catholic liturgy or into its later Protestant liturgical replacements.

\subsection{The Spirit World of Haitian Vodou}

Somewhat more puzzling, however, is the absence of rainfall rituals in Haiti's folk religion, Vodou. Most Kinanbwa villagers, as well as villagers all around Haiti, have practiced their own sui generis rural religion, which emerged during slavery. They refer to it as "serving the lwa" (the major spirits in the pantheon of the folk religion). ${ }^{14}$

Vodou has the three core systemic components that other religions have: (1) spirit beliefs, (2) rituals to interact with the spirits, and (3) ritual leaders who guide and officiate at these interactions. As for (1), the spirit world in Vodou is dominated by an all-powerful but ritually inaccessible supreme deity called by the French-derived name of Bondye- “Good God" (Murray 1985) Most ritual interaction, however, is with two other groups of lesser spirits: the lwa and lemò. The latter are one's dead parents and grandparents. It is the first group, the lwa, who receive the bulk of ritual attention in Vodou. The names of many of the lwa, such as Danbala, Ezili, and Ogoun, indicate that they were brought over by the slaves from West Africa. ${ }^{15}$

However, whereas in the African homeland of the slaves, these were names of separate high deities, in the evolution of rural Vodou the names now refer to separate groups of lwa in different kin groups. The lwa of kin groups in the same region may have the same names and similar characteristics as the lwa of other kin groups. However, they are different spirits. My family Danbala cannot help or hurt an unrelated neighbor-and vice versa (cf. Conway 1978; Smucker 1984; Richman 2005, in chapters 5 and 6, provides what is arguably the most detailed firsthand ethnographic description of the linkage between family and the Vodou spirit world).

As familial spirits, the lwa help only their own human family members. They do not and cannot, however, help communities or regions with rainfall. The lwa, particularly the gentle inherited African lwa ginen, can help their individual "children" if they receive proper ritual attention-food, drink, music, dance, and other ritual courtesies. Among these courtesies are ritual dances called dans vodoun, in which these family lwa are encouraged, via drumming, dancing, and singing of brief songs to the lwa, to momentarily take over the head, mind, and voice of a participating family member and engage in joking conversation with other participants. At that moment, it is the lwa who is speaking, not the person (referred to as the "horse") whom the lwa is momentarily "riding." These events usually occur under the guidance of specialists. Male practitioners are called oungan or gangan; females are called mambo. (Those who specialize in sorcery and black magic are usually called bòkò. Evangelical Protestants may dismiss all oungan as evil bòkò and label all lwa, both sweet and bitter, as djab or satan-Creole for "devil").

In terms of climate issues, none of the central rituals of Vodoun focus on rainfall. Some of the songs occasionally mention the rain. One song concerning "Danbala's stone" recorded by Murray says "jou lapli-a tonbe, ma leve ma wè yo" ("On the day when the rain falls, I'll rise and see them"). Reference is to Neolithic axes—called "thunder stones" - that were made by now-vanished pre-colonial indigenous communities. These stone axe heads are believed to fall from the skies and be buried before rising to the surface when the rain falls. There is no petitionary element in this mention of rain. Danbala can't bring rain.

In short, an important ethnographic fact about the theological premises of Vodou is that the major sphere of activity of the lwa is in the area of health and illness. The most important role of rural

\footnotetext{
14 We are following current practice and call it Vodou, as many anglophone and francophone writers currently do. The term "Vodou" avoids images of "sticking pins in dolls" that the eerie word "voodoo" evokes. Villagers traditionally had no separate noun for their folk-religion; they referred to it with a verb phrase "serving the lwa (spirits)".

15 Hebblethwaite (2015) analyzes historical data on the slave trade from Geggus (1996) to reconstruct the sequence by which different lwa reached the colony of Saint-Domingue from different parts of Africa.
} 
oungan and mambo, the major service for which they are called, is in the diagnosis and healing of illness (cf. Murray 1981; Murray and Alvarez 1981; Conway 1978; Smucker 1984; Vonarx 2011). It is not only the major criterion by which their skills as practitioners are judged by ordinary village adherents, but also their major source of income. They cannot however prevent hurricanes, earthquakes, droughts, and other natural phenomena, which are under the control of another spirit being.

\subsection{The God of Haitian Vodou}

There is another figure in the Vodou pantheon that figures prominently in the minds and daily conversations of villagers but provokes much less interest among anthropologists. This figure is Bondye, the supreme deity, whose exclusive power it is, in local folk-theology, to create life in the womb (Murray 1991), fertility in the crops, and rainfall in the skies (Murray 1985). The power of the lwa and oungan are largely restricted to human minds and bodies. Neither the oungans nor the lwa that they serve can bring rain or cause the crops to grow. In the folk-theology of Vodou, that power is linked to a de-facto division of labor that has been established between the Supreme Being Bondye and the lwa. Power over nature, including rainfall, hurricanes, and earthquakes, is relegated exclusively to Bondye. This concept is by no means limited to Kinanbwa. It also comes out in a direct quote from an elderly Vodou adherent that was recorded in another part of Haiti by Herskovits in the 1930s.

The loa are occupied with men, their task is to cure. They can make a person work better than he otherwise would. When the loa possess people, they can give helpful advice. But they cannot do the things that God does. They can protect a garden, but they cannot make a garden grow. For streams, rain, and thunder come from God.

(Herskovits 1937, p. 142)

In village folk-theology, that power is reserved exclusively to Bondye-God, in English, who is the supreme deity that is at the pinnacle of the Vodou pantheon.

Researchers, however, have shown little interest in Bondye. The colorful, mischievous, and occasionally punitive lwa receive most attention from scholars, particularly foreign scholars. The Haitian scholar Hurbon (1972) has written the only book length treatise on the God figure in Haitian Vodou.

Bondieu's origins are somewhat mysterious. Because he bears the same name as the God of French Catholicism, it is easy to assume that he has been imported into Vodou from the Catholic religion of the former slave masters, as distinct from the African origin of many of the lwa. This assumption should be challenged for at least two reasons. In the first place, the God worshipped in Catholicism is viewed as a trinitarian God who became incarnate as a human being and who is physically present in the Eucharist at Mass. None of these features is even remotely a part of the image of Bondye in Vodou.

Furthermore, in Catholicism, God is the explicit focus of worship, both in public liturgical activities and in private prayer. Other spirits, such as saints and angels, are venerated but secondary. Vodou rituals in contrast restrict ritual activity to the lwa and the ancestral dead. The oungans and mambos do not and cannot officiate at rituals directed to Bondye. (Murray 1985) There is a paralyzing correlate to this situation. God controls the rain, but there is no access to him in the ritual inventory of the specialists of Vodou. Healing is their specialty.

There is, however, a conceptual ploy that permits oungans to perform magic on nature. Farmers know that God makes the seed and the land fertile. However, farmers also know that once the seeds in a field have begun to grow, a jealous neighbor can approach an oungan to purchase a djab to transfer the fertile crops to his own garden, or ordinary thieves can enter the field to steal the crops that are ready to harvest. To protect against this, some farmers purchase and prominently display a protective talisman in their fields to frighten off thieves. Some farmers told Murray that, to save money, they would make fake talismans that would nonetheless frighten off would-be thieves. Likewise, once the rain clouds have been produced by Bondye, some oungan can mobilize a djab to rale lapli-draw the rain-away from its intended destination to the fields of a client (cf. Metraux 1959, pp. 312-13). Additionally, 
though Bondye creates the rain, a lwa or oungan can also mare lapli-tie up the rain when it is excessive (cf. also McAlister 2002, pp. 37-38). In short, Bondye is the Lord of life and of nature. However, once rainclouds exist, the oungan, via a purchased lwa, can steal it away from where God placed it and have the rain fall elsewhere. ${ }^{16}$

\subsection{The Ritual Gap: The Missing Rain Rituals}

Whatever the origin of the Haitian Bondye, his unapproachable throne leaves a ritual gap. The rainfall rituals that we saw in Judaism and in the ethnic religion of Northwest China are absent from the otherwise rich ritual repertoire of Haitian Vodou. They are absent not only in Kinanbwa. We have also searched the abundant literature on Haitian Vodou, including the detailed ethnographies of Herskovits (1937), Metraux (1959), Courlander (1960), Conway (1978), Smucker (1984), Richman (2005), and others. In the rich inventory of studies of Vodou, there is none that describe rain rituals directed to the lwa or to Bondye as an element in the ritual inventory of Vodou.

A reader may legitimately wonder: if there are no rain rituals, why include Vodou in an article on rain rituals? The short answer: anthropology can and should deal with the absence of rain rituals in a setting where they would be expected. The slave ancestors of the Haitians incorporated most West African ritual elements-drumming, dancing, spirit possession, healing rituals, and others-into the ritual inventory of their slave religion. Why did they excluded African rain rituals? The difference between the climate rituals of Judaism and Chinese ethnic religion on the one hand, and the absence of such rituals in Vodou, calls out for comment. This "ritual gap" in Vodou justifies an exploration of why religions veer into different trajectories even when confronted with similar problems. We shall undertake that exploration in the concluding section of the article.

\section{Exploration of Causal Factors}

In the opening paragraphs, we indicated that it is not only the climate that behaves unpredictably; so do religious systems. In this final section, we will examine three paradoxes we have encountered in our comparative analysis and explore possible causal factors nudging each system into its particular ritual trajectory with respect to climate.

\subsection{Israel: Sacred Texts and Adaptive Allegories for the Diaspora}

The paradox in Judaism consists of the survival, during over a millennium and a half, of thrice daily obligatory rituals regarding rainfall and agriculture in Israel that had virtually no relevance to the Jewish people at large, almost all of whom were pursuing non-agrarian urban pursuits in diasporas around the world. We can identify several factors-each of them necessary, but none of them alone sufficient- that have produced the current pattern of climate allusions in the daily liturgy of Judaism.

\section{Ecologically Stressed Agrarian Economy in the Israelite past.}

There are two major material factors-one ecological, the other economic-that led to the birth of a religious concern with Holy Land rainfall in Judaism. The ecological factor is the historically scarce and fluctuating rainfall regime of the Holy Land. The economic factor is the agro-pastoral status of the majority of the Jewish population at the time the two major liturgical texts (the Shma and the Amidah) were composed ${ }^{17}$. There was a Jewish farming population in Israel and (despite urbanization and occupational diversification) most Jews in Israel were still farming the land and raising livestock. It is

16 Murray (1991) documents a similar ritual ploy surrounding the fertility of the female womb. Only God can decree that a child be conceived in the womb. Once the child is there, however, sorcery can "trap" it and arrest its growth. The affected woman is "in perdition". A childless woman may be diagnosed by an oungan as having a child in the womb that has been trapped by a force that the oungan can deal with. This ritual fiction provides hope for the woman (and income for the oungan).

17 Religious Jews might argue that the texts of the Shma were dictated by God to Moses in the Sinai desert. Secular scholars assume that they were written later, when the Jews were already farmers in the Holy Land. 
no surprise that the religious leaders of an ecologically stressed agropastoral economy included climate issues in their public liturgies.

\section{The Reliance on Sacred Written Texts}

That, however, explains the origin, but not the survival, of rainfall rituals after they became irrelevant to the population reciting the prayers. A relatively brief period in the distant past of Jewish involvement in ecologically stressed agriculture does not explain the enigmatic survival of these prayers during two millennia of Jewish life in the urban diasporas of other countries. Muslim farmers had long-ago replaced the Jewish farmers in the territory that was once Israel. The Jews in the urban diaspora for millennia voiced daily rain prayers for Palestine. Did they entertain sustained conscious humanitarian concern for the Muslim farmers of Palestine? It Is unlikely. Nor were the Jews primarily concerned with the land and crops of their diaspora settings. In the first place, diaspora Jews were not and are not farmers. Furthermore, the rainfall texts in the Jewish liturgy apply only to the climate and soil of the Holy Land and immediate surroundings. So the question persists: Why have centuries of Jewish worshippers in the urban diasporas of Europe, North America, and South America continued expressing prayerful concern for rainfall that would benefit the harvests of Arab-speaking Muslim farmers in Palestine?

The answer is to be found in the coalescing of three conceptually independent historical processes that did not co-occur in Chinese shamanism or in Haitian Vodou:

1. reliance on written religious texts,

2. a belief in word-for-word divine revelation behind those texts, and

3. the eventual incorporation by the rabbis of some of these texts as obligatory daily prayers that have to be recited word by word several times a day.

We recall that the synagogue rabbis had replaced the Temple priests as the main religious authorities after the Roman destruction of the Jerusalem Temple. They are the ones who later designed the prayer books with substitute rituals. They are the ones who, out of respect for tradition, mandated diaspora Jewry to continue the daily climate prayers for the Holy Land from which most Jews had long ago emigrated.

Unlike the Chinese Tu and Haitian Vodou, Rabbinic Judaism is based on sacred texts. In Judaism, the most sacred text is the handwritten Torah scroll containing the Five Books of Moses. Every synagogue has one or more of these voluminous Torah scrolls. They must be handwritten by soferim (scribes), much as traditional accounts depict Moses writing down the first twelve Torah scrolls in the Sinai desert (one for each tribe).

However, sacred texts are not enough. The fact that a passage is in the Torah does not mean it will become a dynamic part of Jewish liturgical life. To attain its full power, a passage has to be selected and built into the official daily or weekly liturgy of the religious system. Whereas Judaism encourages spontaneous prayer from the heart, it differs from most other religious systems in the imposition by the rabbis of a daily obligation to recite lengthy formulaic prayers-i.e., pre-written texts that must be prayed word for word every day by religious Jews.

The written instrument for this is the siddur, the Jewish prayer book that places in order the multiple parts of the Jewish daily and weekly liturgy. Whereas the sefer Torah, the Torah scroll, functions as a sacred warehouse containing the entire contents of the five books of Moses, the siddur functions more as a catapult that organizes a subset of texts and prayers that will be shot heavenward several times a day. The siddur contains selections from the Torah and other parts of the Hebrew scriptures, as well as passages from later Jewish writings. The rainfall prayers were included in the two central elements of the siddur, the Shma and the Amidah. These two documents, the sefer Torah and the siddur, have been the core documents around which Jewish synagogue ritual has centered in the centuries following the destruction of the Jerusalem Temple in 70 A.D.

In short, it is the rabbis who have preserved earlier traditional prayer texts. It is also the rabbis who have required recitation of these prayers word for word several times a day from the siddur. 
In short, it is rabbinic decree that has perpetuated the expressions of climate concern in Judaism, even when the passages voicing these concerns were of no relevance, or of marginal relevance, to the diaspora Jews praying the prayers.

\section{The Process of Rabbinic Allegorization}

However, contemporary rabbis seem aware that rainfall in the Holy Land would be of little urgency to Jews in the diaspora. The rabbis have reestablished the relevance of these climate texts by re-defining the prayers for rain as allegories of something else. For the Jewish worshipper in the urban diaspora, the promise of rainfall and the threat of drought in the Shma Israel are frequently interpreted as a generic allegorical allusion to reward and punishment for obeying or disobeying divine commandments. Donin (1980, p. 148), for example, spends nearly two pages discussing the weather passage in the Shma Israel without a single allusion to rain, drought, or crops. He discusses the text as though it concerned only the generic issue of reward and punishment for obeying or violating the 613 commandments binding on Jews. In other words, climate passages have been converted into an allegory of something else. ${ }^{18}$ In a similar manner, modern exegetes or homilists may treat the Amidah's request that God bless the year with rainfall as a prayer that God will bless one's business, one's profession, or one's income. The human brain has the creative power to allegorize, to create similes and metaphors, and to see meaning beyond the literal meaning of words. This power is regularly marshalled, in Judaism, as in other religions ${ }^{19}$, with respect to prayers written thousands of years ago in situations that no longer apply.

Why not eliminate the prayers when they no longer apply to the current circumstances of the population? Some Reform prayer books have precisely done that. In the world of traditional Judaism, however, this is not feasible, desirable, or necessary. In view of the conservative power of the written word, especially the words of sacred texts, it is difficult to eliminate or even change the texts. One does not eliminate texts whose literal meaning has become irrelevant, one simply allegorizes them into some other meaning. ${ }^{20}$ This maintains the relevance of the weather allusions in the Shma and the Amidah among modern Jewish populations where the literal meaning of the text has lost its urgency. Orthodox Jewish business owners, physicians, or lawyers in Paris or Manhattan have no need for rainfall for olive groves and grapevines in Palestine. They have none. However, rainfall and drought have been allegorically converted into promises of reward or threats of punishment for obeying or disobeying the commandments.

Now that Jews constitute a $74 \%$ majority in Israel, however, and now that about half the Jews in the world live in Israel, the prayers for rain retrieve their original relevance. A particularly serious five-year drought ended in 2018. Though much farming is now dependent not on rainfall, but on sophisticated computerized drip irrigation systems, the main source for those systems is water pumped from the Sea of Galilee, a lake in northern Israel. By 2018, the lake had dropped to its lowest recorded

18 Corrigan et al. (1998), in their comparison of Judaism, Christianity, and Islam,) go even further. Their discussions of Jewish ritual look favorably on Reform efforts to update Judaism. Belief in post-mortem reward and punishment, alive and well in the traditional community, is seen by many in the Reform community as part of the obsolete archaisms that should be purged from Jewish religious life. In their treatment of the Shma, they mention neither the literal text of the weather nor the allegorical theme of reward and punishment.

19 Cf. multiple allegorical passages in the New Testament, such as the enigmatic injunction by Jesus not to cast your pearls before swine. The Galilean Jewish disciples to whom this Sermon on the Mount (Mt. chap. 5-7) was directed presumably had few pearls and no pigs.

20 Israeli farmers today, who constitute less than $1 \%$ of the local Jewish population, have no need to allegorize the climate references in the Shema and the Amidah. The Hebrew-speaking settlers in Gaza, among whom (deleted for peer review) lived for several months before their expulsion and the demolition of their homes by the Israeli government, did not depend on rain for their greenhouses, but on a sophisticated computerized drip irrigation system. This system, however, was fed by pipes from northern Israel. Their irrigation system in Gaza, close to Egypt in the south, depended on rain falling up north. They did not grow wheat, grapes, and olives, but flowers for export, including poinsettias for the Christmas market in New York City. Unlike diaspora Jews, these Israeli farmers, who prayed in synagogue every day, had no need to allegorize the rainfall texts. They literally depended on the rain to feed the lake that fed their drip irrigation system. (The past tense is being used. The farmers were subsequently expelled from Gaza by the Israeli government.) 
level since 1920 and was just centimeters from the ecological point of no return in terms of salinity. The Minister of Agriculture called for a special day of prayers. The Chief Rabbis of Israel summoned people to the Western Wall in Jerusalem, Judaism's holiest site, inviting them to pierce the heavens with prayers for rain. (They were warned to bring umbrellas). In line with standard procedure for Jewish weather-crisis rituals, the day chosen was a fast day.

Thousands prayed for rain at the Western Wall, in synagogues throughout Israel, and in the diaspora. It turned out that no umbrellas were needed on that day in Jerusalem. However, as one religious source happily reported (FFOZ 2018), less than a week later, despite gloomy weather forecasts, suddenly " ... the heavens did open up and poured down. It rained for days, filling streams and streets till they gushed, and it even raised the Sea of Galilee ... " For centuries, the rabbis in the diaspora had treated the daily prayers for rain in the Holy Land as allegories of something else. Since the return of Jews to this ecologically vulnerable country, however, the climate prayers for rain have ceased being allegorical. Those reciting them mean exactly what is written.

\subsection{China: Modern Medicine and State-Supported Tourism}

Returning briefly to the Chinese rain rituals, one of the most striking conundrums is the shrinking and virtual disappearance of the traditional healing function of the Tu shaman and his adoption of the weather-control function as the major element in his ritual repertoire. The two functions are not in principle incompatible: the Amidah in Jewish prayer, for example, continues to have a blessing for healing of the sick while another blessing deals with rainfall issues. Why has the Tu shaman, as it were, largely jettisoned one function to pursue the other? The answer involves an unlikely merging of two factors: the spread of modern medical technology combined with the policies of the Chinese government with respect to ethnic traditions and internal tourism.

\section{Decline of Spirit Healing}

A major factor in the transformation of the shamanic role in China has been the spread of institutionalized medicine, both Western biomedicine and Traditional Chinese Medicine (TCM). ${ }^{21}$ The entire Chinese population now has access to hospitals and clinics that specialize in either of those traditions. The Chinese government has made these services widely available throughout China. Few sick people in China today seek out first the service of spirit healers. That particular market for the bo's services has radically dwindled.

At the same time that it has made public medical services available throughout the country, the Chinese government has, ever since the 1980s, been channeling financial and legal support for five officially recognized religions (Daoism, Buddhism, Islam, Catholicism, and Protestantism). Religion has been rescued from the category of "opiate of the masses" to that of a mechanism for much desired "social harmony" (Xing and Murray 2018). ${ }^{22}$ The government also supports "unofficial" village temples, such as those of the Tu, with financial support under the rubric of Support for Intangible Cultural Heritage. It explicitly defines this support to ethnic minorities as a measure for promoting local income generation. It pursues income generation among ethnic minorities by supporting displays of traditional culture to the growing tourist market, well over $95 \%$ of which is internal tourism from other parts of China. The Northwest region of the Tu is located at $3000 \mathrm{~m}$ altitude on the Tibetan plateau and remains cool during the hot summer months when residents of Beijing, Nanjing, Shanghai,

21 It must be pointed out that TCM does not entail spirit healing. A major diagnostic emphasis is on discovering imbalances in the flows of energy $(q i)$ in the human body of a sick person. Healing entails the reestablishment of the proper energy flows. Neither in diagnosis nor in therapy do TCM doctors invoke or consult with spirit beings.

22 To avoid romanticizing, recent events involving the Muslim Uighur of Xinjiang and crackdown on Christian churches could be interpreted as the pendulum swinging back. In the case of Islam, the reversal could also be seen as simply a continuation and radical application of a fierce determination to stamp out any perceived threat to "national unity", as defined by the Party. If this interpretation is correct, ethnic diversity will continue to be supported as long as it does not cross certain political lines. The final chapter has yet to be written. 
and other densely populated regions in the east of China increasingly seek summer respite from the heat and the air pollution of eastern China. This northern Tu region of Qinghai province is becoming a favored destination.

The Chinese government provides financial support and encouragement to ethnic minority groups all over China to plug into this internal Chinese tourist market by making displays of their traditional ethnic culture. Some groups produce material handicrafts, such as the batik of the Miao and the embroidery of the Tu. In addition to ethnic handicrafts, the Tu and many other groups are also encouraged to organize and stage for the visitors performances of their ethnic culture using local clothing, songs, dances, and other performative elements. In dealing with these "religious" performances for tourists, the Tu engage in no pretense. They make a distinction between the "real rituals", which are held in Tu villages in March at the beginning of the rainy season, and the "tourist rituals", which come in later months when tourists escape the summer heat and air pollution of the cities of eastern China. For the latter, young people among the Tu are trained (and paid) to reenact the rainfall rituals for tourists in the special "traditional compound", which the government has financed for such income-generating events. The Tu recognize these events as "make believe" performances that are staged only for the tourists, not bona fide religious rituals.

There is, however, one major exception to the government's willingness to support ethnic traditions. There is one element of traditional culture that the Chinese government most emphatically does not support: spirit healing. The above-mentioned decline in demand for spirit healing services due to the spread of modern medicine has been accompanied by an increase in the level of scorn-both official governmental scorn and informal popular scorn - publicly expressed for the incantations and procedures of spirit healers. The healer's ritual chants are mocked by many as the "mumbo jumbo hocus pocus" of income-seeking charlatans who prey on the ignorance of the poorly educated and the gullible. Shamanic spirit healing is not part of the Intangible Cultural Heritage that is publicly encouraged and financially supported by the government of China.

This places the Tu shaman, the $b o$, at an economic and social crossroads. His income from spirit healing had already begun to decline with the spread of institutional medicine. Moreover, the official attitude, as well as the unofficial public attitude, to his spirit healing activities is increasingly negative. He could, in addition, even be punished for practicing medicine without a license. On the other hand, the same authority also encourages the Tu to stage cultural performances for visitors from other parts of China. Among the Tu, most cultural performances are religious in character; and the most important public rituals are related to rainfall. Neither government officials nor urban visitors from Beijing or Shanghai may believe that spirits have power over the rain. However, the rainfall dances and songs are done by Tu youth as demonstrations of ethnic traditions, not as religious rituals. Even though the elderly $b o$ does not participate in these tourist shows, he now receives a salary from the government as a certified expert in Tu culture and participates in the training of the young actors who will perform for tourists.

He does not, however, train them to perform shamanistic healing rituals. Healing rituals are inherently private and involve individuals who are suffering or dying. Such healing scenes are hardly matter for a public performance in front of tourists. They would provoke mockery. Rain rituals, in contrast, with colorful costumes, songs, and dances, are felt to be legitimate manifestations of local culture worthy of display to outsiders and therefore able to generate income, both indirectly for the bo and directly for the youth trained to enact the performance in front of tourists.

These considerations answer the question that was posed: Why have climate control issues replaced healing as the major function of the Tu $b o$ ? Viewed in this context, the choice seems rational. It is no mystery that the bo has increasingly opted for leadership in collective, governmentally supported rainfall rituals and has largely withdrawn from private, socially marginal, and legally suspect healing rituals. 


\subsection{Haiti: The Impact of Slavery and Stratified Theological Syncretism}

With the $\mathrm{Tu}$, we were impressed with the growing importance of rain rituals. The opposite enigma was found in Haitian Vodou: we are impressed at the absence of rainfall rituals. The religions practiced in West African homelands of the slaves did have a rich panoply of elements: spirit beliefs, drumming, singing, dancing, spirit possession, animal sacrifice, healing rituals, rainfall rituals, and many others. As Gumo (2017) points out, rainmaking rituals were a key element in African societies. Community rainfall rituals were found among the Igbos of Nigeria, many of whom were transported as slaves to French Saint Domingue. Haitian Vodou incorporated many of the elements found in West African religions-but not the rainfall rituals.

\section{The Causal Impact of Slavery}

Why were West African climate-related rituals not brought over to Haiti, as were other elements of African religions? Let us change the question. Why should they have been brought over? Why would agrarian slaves in one of the most vicious variants of European slavery be concerned with petitioning the spirit world for timely rains for the fields and crops of the masters?

Short answer: They were understandably not concerned.

Therefore, though elements of West African ritual such as drumming, spirit possession, healing and others found a place in the evolving Vodou ritual of the slaves, West African rainfall rituals that would have benefitted the masters' crops did not. Were these rituals intentionally excluded? Not necessarily. Would it have even occurred to slaves, in their secret nocturnal rituals that were looked on by the masters with suspicion, to include rituals for the prosperity of French sugar cane and coffee plantations? It is unlikely. Vodou was reportedly ${ }^{23}$ mobilized by the slaves, in 1791 , as a vehicle of revolt against the French masters, not as a vehicle for ensuring the fertility of the masters' fields. By the time a peasant society emerged after 1804 in post-revolutionary Haiti under the leadership of Creole slaves born in the colony, most of the slaves who had come from Africa as adults were long dead, and any African rain rituals they may have observed were long forgotten. They never entered the liturgical repertoire of Vodou. In short, we propose that slavery was a major causal factor in the exclusion of rain rituals from the birth of Haitian Vodou. ${ }^{24}$

\section{The causal impact of a theological premise}

However, there was a second powerful factor, beyond slavery, something we mentioned above. There arose in Haitian Vodou a folk-theological premise that militated against the later emergence of climate rituals. This has to do with what could be labeled stratified theological syncretism: a theological postulate in Vodou that posits an active-but-inaccessible Supreme Being who differs both from his African and Euro-Christian counterparts. Unlike the deus otiosus of West Africa, the high deities who are too distant to become involved in daily human affairs, the Bondye of Haitian folk religion is an active force, not only in rainfall and the fertility of crops, but even in the fertility of humans and animals. Unlike the Christian image of God, however, he is not the object either of public rituals or of private petitions in Vodou. It is viewed as risky even to try. When Murray posed questions to individuals as to how many children they would like to have, the answer was usually: "It's up to Bondye. Whatever he gives me is fine". It was clear from other data that people were not indifferent to the number of their offspring; the question was simply being dodged. Murray tried a follow-up question: What would you say to Bondye if he asked you how many children you want? This question was also dodged.

23 Some scholars view the revolutionary role of Vodou as a romanticized exaggeration. The discussion falls outside this article.

24 The hypothesis could be validated or falsified by searching for rainfall rituals in other well-known Afro-Caribbean and Afro-Brazilian religious systems that also arose during slavery. Among these are Trinidadian Shango, Cuban Santeria, and Brazilian Candomble. In a brief perusal we have found no rain rituals. But systematic research on this specific question has yet to be carried out. 
Several village women explained: "If you ask Bondye for two children, he may give you eight. If you ask him for five, he may give you only one or none." It is best not to express an opinion.

However, we can recall that Bondye not only controls human fertility. He also decides whether there will be rain or drought. By the same folk-theological logic, therefore, it is safer not to address climate petitions to him. Therefore, in addition to the slavery factor that, in our view, suppressed rain rituals at the birth of Vodou, the additional folk-theological postulate of a powerful but unapproachable Supreme Being is another factor underlying the absence of rainfall rituals. In the face of drought, or in the face of a fierce hurricane, or in the face of the 2010 earthquake, the major (and safest) exclamation heard from Haitian lips is: Bondye bon! God is good. Not even the most devoted Vodou adherents pepper their daily speech with affirmations that "Danbala is good" or "Ezili is good." In contrast, Bondye bon is heard on the lips of Haitians of all religious groups. However, no collective Vodou petitions are issued to Bondye by oungans or their clients, and certainly no collective complaints are voiced. Bondye bon. God is good. It is safest to leave it at that.

\section{Summary and Conclusion: Identifying a Common Causal Force}

\subsection{The Impact of State Power on the Evolution of Religion}

In this final section, we will discuss a unifying theme that has informed the evolution of all three systems: response to State behavior. In all three systems, a macro-political variable- the behavior of the State-not directly linked to ecological concerns has exerted a major impact on the evolution (or suppression) of rain rituals. We can summarize the dynamics sequentially.

\section{Impact of State power on Judaism}

It was the power of the Roman State in 70 CE that destroyed the sacrificial rituals of Temple Judaism and led to the emergence of contemporary Rabbinic Judaism. The Jewish farming population survived in Palestine under later Roman and early Byzantine States. Daily synagogue prayer and textual exegesis replaced animal sacrifice as the major ritual focus. It was at this phase that rain rituals, of importance to the Jewish farmers who were still a majority in Palestine. entered the Jewish prayer book under rabbinic authority.

However, the arrival of another State-the Islamic State-in 636 CE eventually brought an end to Jewish farming in Palestine, as most Jews eventually opted for emigration from the Holy Land. However, since the rainfall passages had become a core element in the Shma Israel and the Amidah prayers, these prayers for rain in Palestine were carried by Jews, under rabbinic supervision, into the diaspora. No longer of literal relevance, we have seen that the logic of the rainfall passages was preserved by converting them into allegories of reward and punishment for obeying or violating the 613 commandments. As a further causal insight, we can see that the Hebrew-language siddur, the Jewish prayerbook, was a unifying force contributing to the survival of the Jewish population as an ethnic minority under the different States of the diaspora. The invention of printing led to a further homogenization and standardization of different variants of the Hebrew siddur in different parts of the Jewish world (Jacobson 1966). The daily use of the Hebrew prayerbook by Jews who no longer spoke Hebrew as their mother tongue contributed to continuity of Jewish religious and cultural identity in settings in which other groups were absorbed into local cultures and disappeared as discrete sociocultural entities. Jewish rainfall rituals are part of this historically unusual survival story, as Jews have adapted to different State powers throughout history.

We can see three distinct phases of Jewish response to State power. (1) the Roman State destroyed Temple Judaism and paved the way for Rabbinic Judaism. (2) the Islamic caliphates in Palestine led to emigration and conversion of Jews into stateless minorities in different lands; and (3) the rabbinic success in preserving daily prayers in Hebrew for Jews around the world who no longer spoke Hebrew allowed Jews to resist the State-supported forces for religious and cultural assimilation that led to the disappearance of other ethnic minorities. Therefore, the rabbinically mandated rainfall prayers for 
Palestine, recited thrice-daily in Hebrew, were among the vehicles that contributed to the unusual survival of Jews as a distinct, self-conscious ethnic group in States around the world that successfully absorbed, diluted, assimilated, and eliminated other ethnic minorities.

\section{Impact of State power on ethnic Chinese religion}

We have also seen the causal impact of State power on the rainfall element in ethnic Chinese religion. The Cultural Revolution of the 1960s and 1970s was supported by the Chinese State. It attempted, but failed, to eradicate religion from the cultural repertoire of the Chinese population. A turnabout and reversal of Chinese State policy regarding religion, initiated in the late 1970s and 1980s, led to financial support for five officially recognized religions: Daoism, Buddhism, Islam, Catholicism, and Protestantism. Ethnic minority religions, such as that of the Tu, are not officially supported by the Chinese State. However, they are discreetly supported via a program to preserve Cultural Heritage. This support targets features appropriate for theatrical displays to Chinese tourists. We have seen that the rainfall rituals fit neatly into this State agenda. At the same time, a continuing State hostility toward a major element of folk religions, spirit healing, has contributed to a redefinition of the shamanic role among the Tu. State hostility to spirit healing force him to downplay his healer role and upgrade his role as a salaried "cultural expert" who trains younger Tu in the public enactment of rainfall performances for tourists. In short, as with Judaism, ethnic Chinese religion has adapted itself to the shifting manifestations of State power. The adaptations have been quite different. However, both religious systems have adapted to State power.

\section{Impact of State Power on Haitian Vodou}

The rainfall issue in Vodou differs radically from that of Judaism and Chinese ethnic religion. However the exercise of State power-the creation and enforcement of a slave system-can also be invoked here as a major causal force. The paradox in Vodou is the absence of rain rituals in the religion of an agrarian population suffering the ravages of climate change and drought. Their African ancestors had rain rituals that could have been incorporated into the slave religion, just as the possession, drumming, dancing, and healing rituals were brought from Africa. However, the rain rituals were excluded. Again, we can look to the impact of the behavior of States, in particular to the State-organized slave system. African States of the Atlantic coast collaborated with European colonial States to capture and sell African slaves. The colonial State in Saint Domingue organized and enforced the slave labor arrangement. We have argued that it is no surprise that the slaves did not include in their evolving religious repertoire any rituals guaranteeing the fertility of the masters' land. In short, the climate elements in all three religious systems, each in its own way, has had to adapt to the impact of the behavior of the State.

\subsection{Cautions about Causality}

Our cases show clearly that the presence or absence of rainfall rituals cannot be simplistically attributed to climate stress or other ecological variables. In favor of ecology-as-cause, it is probably the case that rain rituals are more likely to appear among agrarian groups dependent on rain for their very livelihood. This was true of Palestinian Jewish farmers in the centuries following the destruction of the Temple, before the arrival of the Islamic State. It has been true of the Tu of northwestern China, who are still farmers, and who maintain their own temples to practice rain rituals that are not part of the Tibetan Buddhism that dominates the region. That is, there is probably an ecological component, related to farming, that feeds into the genesis of rain rituals. However, we have seen in both Judaism and Haitian Vodou, that rain rituals can survive even when the ecological setting of those practicing the rituals would no longer warrant them, or that rain rituals can be excluded, as in the French slave colony of Saint Domingue, even when the local agrarian ecology would seem to call for them. Our findings show clearly that simplistic models of ecological causality should be treated with skepticism. 
On the other hand, we reject with equal firmness any proposition that would exempt or exclude religious systems from any attempt at causal analysis. A certain type of earlier anthropological analysis would classify religion-particularly an unofficial folk-religion-as a cultural inscrutable that should be ethnographically described but not "explained". The search for causes was in effect verboten. We have argued, in contrast, that for each religious system there are identifiable causal factors that have contributed to the inclusion or exclusion of rain rituals. As a common unifying theme, the policies and behavior of States are among the factors that have triggered changes in the three religious systems that we have examined.

It is important, however, to avoid caricatures about how States influence religion. A simplistic conspiracy model would depict manipulative State bureaucrats rubbing their hands behind the scenes as they consciously design self-serving theologies that will be peddled to the masses. This cartoon scenario is not how State power has operated in the three cases that we have studied. What has happened instead is that the behavior of the State, through military conquest, slavery, or other processes, creates conditions that, often unbeknownst to the rulers themselves, forces local religious systems into adaptive maneuvers. One need not concoct conscious Machiavellian planning on the part of State authorities to posit an impact of State power on the evolution of a religious system.

Furthermore, just as we have avoided simplistic ecological causality, so also we should avoid elevating State power as the only or even major causal determinant of religious belief and practice. We have seen the operation of other causal factors not directly attributable to State power. The impact of writing, for example, in particular the tenacity of sacred texts used in formulaic prayer, has exercised a heavy causal impact on the counterintuitive maintenance of climate concerns in the liturgy of diaspora Judaism. A theological variable has intervened in Haiti: the yet-unexplained belief in Haitian village Vodou of an active-but-unapproachable supreme deity, Bondye, different from both the Christian trinity and the distant, uninvolved supreme deus otiosus of West African traditions. Whatever his origin, the unapproachable character of the Vodou Bondye who is in charge of rainfall and fertility issues has contributed to the absence of rainfall rituals independently of the State-mandated slave status of Haiti's ancestral population. In short, neither ecological factors nor the behavior of the State are the only causal forces that effect the evolutionary trajectory of a religious system. We have seen the operation of a variety of other causal factors.

Whatever the analytic complexities, we view as one of anthropology's major strengths its ability to perform three sequentially organized intellectual operations on cultural subsystems such as religion: (1) detailed ethnographic description of individual systems; (2) ethnological comparison and contrast of specific elements in different systems; and (3) attempts at explanation of the causal forces that may have contributed both to the similarities and to the differences among systems. We have attempted to apply this conceptual paradigm to the differing responses of religious systems in Israel, China, and Haiti to issues of climate stress and climate change.

Author Contributions: H.X.'s fieldwork among the Tu of Northwest China was the basis for the Chinese component of the article. G.M. has done fieldwork among Haitian villagers and religious Israeli farmers. G.M. provided the conceptualization behind the comparative analysis, was responsible for the first draft of the article, and responded to anonymous reviewer comments. G.M. and H.X. both responded to editorial recommendations by the editorial staff of the journal. All authors have read and agreed to the published version of the manuscript.

Funding: Murray's original funding in Haiti came through Columbia University's International Institute for the Study of Human Reproduction, in collaboration with the Centre d'Hygiène Familiale in Port-au-Prince Haiti. Subsequent field trips to Haiti were financed under contract with the U.S. State Department's Agency for International Development. His research in Israel was supported by the University of Florida's Center for Jewish Studies. Xing's research in China was supported by the National Social Science Foundation of China (Grant No. 17BMZ047).

Acknowledgments: We are grateful for the helpful suggestions of anonymous reviewer \#2. We are also grateful to Daniel Yelenik and Margaret Rappaport for their comments on a preliminary draft.

Conflicts of Interest: The authors declare no conflict of interest. 


\section{References}

Cartwright, Mark. 2017. The Dragon in Ancient China. Ancient History Encyclopedia. Available online: https://www.ancient.eu/article/1125/the-dragon-in-ancient-china/ (accessed on 3 June 2020).

Central Intelligence Agency. 2019. The World Factbook. "Israel”. Available online: https://www.cia.gov/library/ publications/the-world-factbook/geos/is.html (accessed on 3 June 2020).

Conway, Frederick. 1978. Pentecostalism in the Context of Haitian Religion and Health Practice. Ph.D. dissertation, The American University, Washington, DC, USA.

Corrigan, John, Frederick Denny, Carlos Eire, and Martin Jaffee. 1998. Jews, Christians, Muslims: A Comparative Introduction to Monotheistic Religions. Upper Saddle River: Prentice-Hall.

Courlander, Harold. 1960. The Drum and the Hoe. Berkeley: U. of California Press.

Donin, Hayim H. 1980. To Pray as a Jew: A Guide to the Prayer Book and the Synagogue Service. New York: Basic Books.

FFOZ. 2018. "Six Years of Drought in Israel." First Fruits of Zion. November 7. Available online: https: //ffoz.org/discover/israel-news/six-years-of-drought-in-israel.html (accessed on 20 June 2020).

Geggus, David. 1996. Sex Ratio, Age and Ethnicity in the Atlantic Slave Trade: Data from French Shipping and Plantation Records. In Slave Trades, 1500-1800: Globalization of Forced Labour. Edited by Manning Patrick. Vermont: Brookfield, pp. 257-78.

Gumo, Sussy. 2017. Praying for Rain: Indigenous Systems of Rainmaking in Kenya. The Ecumenical Review 69: 386-97. Available online: https://doi.org/10.1111/erev.12301 (accessed on 17 March 2020). [CrossRef]

Hebblethwaite, Benjamin. 2015. Historical Linguistic Approaches to Haitian Creole. La Española: Isla de Encuentros, Hispaniola: Island of Encounters, Available online: https://www.academia.edu/24406296 (accessed on 15 May 2020).

Herskovits, Melville. 1937. Life in a Haitian Valley. New York: Knopf.

Hurbon, Laennec. 1972. Dieu dans le Vodou Haïtien. Paris: Payot.

Jacobson, B. S. 1966. Meditations on the Siddur. Tel Aviv: Sinai Publishing.

McAlister, Elizabeth. 2002. Rara: Vodou, Power, and Performance in Haiti and Its Diaspora. Berkeley: U. of California Press.

Metraux, Alfred. 1959. Voodoo in Haiti. New York: Schocken.

Murray, Gerald. 1968. La Loma: Economy and Worldview among Mountain Peasants of the Dominican Republic. Senior Honors thesis, Harvard College, Harvard, MA, USA.

Murray, Gerald. 1977. The Evolution of Haitian Peasant Land Tenure: A Case Study in Agrarian Adaptation to Population Growth. Ph.D. Dissertation, Columbia University, Department of Anthropology, New York, NY, USA.

Murray, Gerald. 1981. Peasant Tree Planting in Haiti: A Social Soundness Analysis; Port-au-Prince: USAID.

Murray, Gerald. 1985. Bon-Dieu and the rites of passage in rural Haiti: Structural determinants of postcolonial religion. In The Catholic Church and religions in Latin America. Edited by Thomas C. Bruneau, Chester E. Gabriel and Mary Mooney. Montreal: Centre for Developing-Area Studies, McGill University, pp. 188-231.

Murray, Gerald. 1991. The phantom child in Haitian Voodoo: A folk-religious model of uterine life. In African Creative Expressions of the Divine. Edited by Kortright Davis, Elias Farajaje-Jones and Iris Eaton. Washington, DC: Howard University Press, pp. 4-26.

Murray, Gerald, and Maria Alvarez. 1981. Socialization for Scarcity: Child Feeding Practices and Beliefs in a Haitian Village; Port-au-Prince: United States Agency for International Development.

Richman, Karen. 2005. Migration and Vodou. Gainesville: University Press of Florida.

Sherman, Nosson, and Meir Zlotowitz, eds. 1985. The Complete ArtScroll Siddur. Brooklyn: Mesorah Publications.

Smucker, Glenn. 1984. Peasants and Development Politics: A Study in Haitian Class and Culture. Ph.D. dissertation, New School for Social Research, New York, NY, USA.

Staub, Caroline, Anne Gilot, Molene Pierre, Gerald Murray, and Rosalie Koenig. 2020. Coping with climatic shocks: Local perspectives from Haiti's rural mountain regions. Population and Environment. [CrossRef]

Talmud, Tanit 19a. n.d. Choni the Circle-Maker. Available online: https://www.chabad.org/library/article_cdo/aid /448345/jewish/Choni-the-Circle-Maker.htm (accessed on 15 June 2020).

Vonarx, Nicolas. 2011. Le Vodou Haitien: Entre Médecine, Magie et Religion. Quebec: Les Presses de l'Université Laval.

Xing, Haiyan. 2015. Social Maintenance and Cultural Continuity_Folk Religion among the Tu in the Northwest China. Ph.D. dissertation, University of Florida, Gainesville, FL, USA. 
Xing, Haiyan, and Gerald Murray. 2018. The evolution of Chinese shamanism: A case study from Northwest China. Religions 9: 397. [CrossRef]

Xing, Haiyan, and Gerald Murray. 2019. Gender and folk-religion in Western China: A Case study of the Tu of Qinghai. Religions 10: 526. [CrossRef]

Publisher's Note: MDPI stays neutral with regard to jurisdictional claims in published maps and institutional affiliations.

(C) 2020 by the authors. Licensee MDPI, Basel, Switzerland. This article is an open access article distributed under the terms and conditions of the Creative Commons Attribution (CC BY) license (http://creativecommons.org/licenses/by/4.0/). 